DOI: https://doi.org/10.24127/ajpm.v9i2.2778

\title{
THE DIFFERENCES OF COGNITIVE STYLE FIELDS-INDEPENDENT AND DEPENDENT ON STUDENTS' MATHEMATICAL PROBLEM SOLVING ABILITIES
}

\author{
Hasbullah $^{1}$, Supardi Uki Sajiman ${ }^{2}$ \\ ${ }^{1,2}$ Pendidikan Matematika Universitas Indraprasta PGRI, Jakarta Selatan, Indonesia \\ E-mail: $\quad \frac{\text { hasbullah@unindra.ac.id }}{\text { supardi@unindra.ac.id }}{ }^{\text {I) }}$
}

Received 26 April 2020; Received in revised form 21 June 2020; Accepted 28 June 2020

\begin{abstract}
The study aims to determine the differences in field-independent cognitive styles with a dependent on students' mathematical problem solving abilities. This researcher uses a quantitative approach with a correlational survey method with factual exposure research types. The study population was the seventh grade students of Madrasah Tsanawiyah in Lombok Timur, amounting to 680. The sampling used was simple random sampling technique. The sampling technique uses percentage techniques. From a population of 680 people are taken $10 \%$, so the number of samples in this study was 68 people. The hypothesis analysis test used the t test with SPSS 22. The results showed that there was a difference between students' mathematical problem solving abilities in the group of students who had a field independent cognitive style and a group of students who had a field dependent cognitive style. the principal in recruiting students to enter the Madrasah Tsnawiyah, not only the value of the results of the National Primary School exam but rather the grouping of students based on independent and field dependent cognitive field styles
\end{abstract}

Keywords: Cognitive style; field dependent; field independent; problem solving.

\section{INTRODUCTION}

The purpose of mathematics learning consists based on NCTM of: 1) Problem Solving, 2) Reasoning and Proof, 3) Communication, 4) Connections, 5) Representation (Mauleto, 2019). Various purposes of mathematics learning, one of which is the ability of high-level thinking that students need in this century is the ability to problem solving (Elita et al., 2019).

Problem-solving is an important activity in mathematics learning activities and is the main focus of the mathematics curriculum. problem-solving is related to optimizing imagination, new ideas, the ability to think and combine new rules, because problem-solving must gather subobjectives to achieve goals (Nasution, 2013).
Suggests problem solving skills is an individual's ability to find a way out of a problem that is a thirst for the purpose of obtaining knowledge and understanding of the scientific concept of thinking (Ilmiyana, 2018). Problem solving is an intellectual activity to find a solution to solving problems involving knowledge and experience (Maimunah et al., 2016). While solving the problem in Metematika itself is an effort that students have in solving math problems by involving all the knowledge and experience they have (Padliani et al., 2019).

The effort that students have in solving problems requires process. Nur and Palobo stated that the problemsolving process is a complex process that requires flexible and dynamic minds (Purwaningsih \& Ardani, 2020). According to Polya, the problem 
solving process has an four of stages namely: 1) Understanding and representing problems, 2) Choosing or planning solutions, 3) Resolving problems according to plan, and 4) Reexamining the results obtained (Sunandar et al., 2018).

The students' mathematical problem-solving abilities are influenced by various factors, one of which is the student's characteristic factor. Characteristics of students that have implications for mathematics learning are student cognitive styles (Spector, 2012). This is in accordance with the opinion Vedigarys, that the selection of solutions in problem solving can be due to differences in cognitive style (Vendiagrys et al., 2015).

Cognitive style is a person's style of thinking involving cognitive ability in relation to how individuals receive, store, process and present information (Suryanti, 2014). The equivalent of Kafiar (2015) states that cognitive styles are a typical student way of learning, both relating to the acceptance and processing of information, attitudes towards information, and habits related to the learning environment.

The cognitive style consists of various types. One type of cognitive style type of interpersonal behavior, social skills, and receiving information is field dependent and field independent (Mourlas et al., 2015). The characteristics of field independent learners consist of: 1) having analytical perceptions, 2) oriented individuals, 3) remembering material by making their own goals based on concept maps, 4) receiving intrinsic reinforcement, 5) attraction of abstract learning or theory and analysis , 6) better in solving problems that require knowledge, while field-dependent cognitive styles are characterized by indicators: 1) having global perceptions, 2) social oriented, 3) remembering material by following existing goals, 4) receiving extrinsic reinforcement, 5) the attractiveness of learning in terms of social skills, 6) not good at solving problems that require knowledge (Stavredes, 2011; Yousefi, 2011).

Many studies on the cognitive style of students ' mathematical problem solving skills such as Ulya (2015) Research on junior high schools showed that there was a significant positive relationship between students cognitive styles with student problem solving skills. The same research results were done by Prabawa \& Zaenuri (2017) that problem solving ability students with the cognitive style of Field Independent (FI) tend to have better problem-solving skills than students with a Field Dependent (FD) cognitive style. While another study conducted Nurmutia (2019) showed a strong positive relationship between cognitive style and mathematical problem solving skills.

Some of the above studies, have similarities with the research conducted, but the average research above shows the use of a poll on the field dependent cognitive style and the independent using an existing poll. While the study uses selfdeveloped cognitive-style polls by authors (Sajiman \& Hasbullah, 2016), so it strengthens researchers to conduct research. The novelty of this research is on the instrument of the cognitive style field dependent and independent.

The Results of observations and interviews conducted by the study of teachers in Madrasah Tsanawiyah show that Especially on students ' ability to solve problems is still relatively low. The low ability of 
students' mathematical problem solving is seen from: 1) When faced with a story problem, students are not accustomed to writing what is known and what is asked of the problem before completing it, so students often misinterpret the purpose of the problem, 2) Lack of precision students in mentioning symbols or mathematical notation, for example that most students still cannot distinguish between symbols for set slices and symbols for set combinations, 3) There is a doubtful attitude of students to communicate mathematical ideas such as the completion of story questions.

Based on the background, this research aims to describe the influence of field dependent cognitive style and independent of the mathematical problem solving skills of students of Madrasah Tsanawiyah class VII in East Lombok.

\section{METHOD}

This researcher uses a quantitative approach. Whereas the method used is a correlational survey method with factual exposure type research.

The study population was VII grade students Madrasah Tsanawiyah Lombok Timur which amounts to 680 . Sampling uses a simple random sampling technique, because sample is homogeneous (Alvi, 2016). The sampling technique uses percentage techniques. From the total population of 680 people was taken $10 \%$, so the number of samples in this study amounted to 68 people.

The independent variable in this study is a cognitive style which consists of independent cognitive styles and cognitive dependent styles. Cognitive style data was collected by non-test instruments (questionnaires) that were developed independently by researchers involving psychology experts. Cognitive style indicators consist of 1) perceiving the surrounding environment, 2) Orientation in processing information, 3 ) remembering subject matter, 4) Form of selfmotivation in storing information, 5) Interest in learning, 6) Resolving a problem that requires skills. The number of items in the cognitive style questionnaire statement was 50 consisting of 25 items of independent cognitive style and 25 items of cognitive dependent style.

While the dependent variable i.e. the ability to solve mathematical problems as measured by tests. The number of questions measured is 10 questions. Before the question is given to the sample, the researcher first tests the construct validity by involving mathematicians from the college and empirical validity test using the Product Moment Correlation, because the form of the instrument has more than two responses (Lochmiller \& Lester, 2017). Reliability test using Cronbach Alpha, because the test instrument of mathematical problem-solving ability has a form of a scale (Huisman \& Tight, 2015). Of the 10 questions, only 9 questions are valid and are used to test students' problem-solving skills.

The hypothesis analysis test uses t-test with SPSS 22. Before analyzing the data, the data were tested for normality and homogeneity of variance. Anova is carried out by looking at the hypothesis criteria:

Ho: There is no influence of cognitive style on the ability to solve mathematical problems of Madrasah Tsanawiyah students.

Ha: And the influence of cognitive style on mathematical problem-solving abilities of Madrasah Tsanawiyah students. 


\section{RESULT AND DISCUSSION}

The mathematical problem solving abilities of students with independent field cognitive styles obtained the following results: number of respondents 34 people, minimum score 60 , maximum score 82 , average score was 68.53, mode 60, median 67 and standard deviation 7.145. While the mathematical problem solving abilities of students with cognitive field dependent styles obtained the following results: the number of respondents 34 people, a minimum score of 52 , a maximum score of 72 , the average score is 63.65 , mode 59.37 , median 63.5 and standard deviation 5,382. for hypothesis testing is presented in Table 1.

Table 1. Hipotesis

\begin{tabular}{lllllllll}
\hline & & \multicolumn{3}{c}{$\begin{array}{l}\text { Levene's Test } \\
\text { for Equality } \\
\text { of Variances }\end{array}$} & & & t-test for Equality of Means \\
\cline { 2 - 8 } & & F & Sig & t & df & Sig & $\begin{array}{c}\text { Mean } \\
\text { Difference }\end{array}$ \\
\hline $\begin{array}{l}\text { Problem } \\
\text { solving } \\
\text { ability }\end{array}$ & $\begin{array}{l}\text { Equal } \\
\text { variances } \\
\text { Equal } \\
\text { variances not } \\
\text { assumed }\end{array}$ & 3,512 &, 065 & 3,183 & 66 &, 002 & 4,882 \\
& & & & 3,183 & 61,328 &, 002 & 4,882 \\
\hline
\end{tabular}

Based on the results of the calculation of the two difference test average data presented in Table 1 , it is known that in the Levene's Test for Equality of Variances column it has a significance value of $0.65>0.05$. This shows that the two variances are the same, then the use of variance to compare population averages ( $\mathrm{t}$-test for Equality of Means) in t-test testing must be based on the equal variance assumed.
At equal variance assumed $\mathrm{t}$ value obtained is 3.183 and significance level $p=0.002$. These results indicate that $p$ $<0.05$, means that there are differences in mathematical problem solving abilities in terms of students' cognitive styles. This has the meaning that students' mathematical problem solving abilities between field-independent cognitive styles are different dependent.

Tabel 2. Description of statistic group.

\begin{tabular}{llrrrr}
\hline & Cognitve_Style & N & \multicolumn{1}{c}{ Mean } & \multicolumn{1}{c}{$\begin{array}{c}\text { Std. } \\
\text { Deviation }\end{array}$} & \multicolumn{1}{c}{$\begin{array}{c}\text { Std. Error } \\
\text { Mean }\end{array}$} \\
\hline Problem & Field Independent & 34 & 68,53 & 7,145 & 1,225 \\
solving ability & Field Dependent & 34 & 63,65 & 5,382 &, 923 \\
\hline
\end{tabular}

Based on the Table 2, the mean value at Field-independent is 68.53 and Field-dependent is 63.65. This value means that the average mathematical problem solving ability of students in field-independent cognitive style is
68.53 and the average mathematical problem solving ability of students in field-dependent cognitive style is 63.65 . Thus it can be said that the level of mathematical problem solving abilities of students between field-independent 
cognitive styles is higher than fielddependent cognitive styles. Thus the research hypothesis which states that there is a difference between students' mathematical problem solving abilities in groups of students who have a field independent cognitive style and groups of students who have a field dependent cognitive style has been verified.

Based on the results of hypothesis testing showing that there are differences students' mathematical problem solving abilities between the cognitive style Field Independent with Cognitive Style of Dependent Field. This finding supports the research hypothesis which states that there are differences in mathematical problem solving abilities of students who have a cognitive Field Independent Style with students who have a cognitive Field Dependent Style. This result is also in accordance with the acquisition of the average value of mathematical problem solving abilities of students in students who have the Field Independent cognitive style $\mathbf{=} \mathbf{6 8 . 5 3}$ is higher than the acquisition of the value of mathematical problem solving abilities that have the cognitive style of the Dependent Field with an average = 63.65. These results indicate that mathematical problem solving abilities are groups of students who have a Field Independent cognitive style tow more than the group of students who have cognitive style Field Dependent.

The results of this study are reinforced by the results of other studies stating that The students' independent cognitive style achieved was higher than their dependent cognitive style counterpart in the Mathematics Achievement Test (Umaru \& Tukur, 2013). This study concludes that students who have a Field Independent cognitive style are higher than students who have a Field Dependent cognitive style in mathematics learning. This result is also in accordance with the research conducted by This result is also in accordance with with the research conducted by Alifah \& Aripin (2018) that students who Field Dependent shows a solution of problems acquired without the proper argument based so as to be less able to solve mathematical problems. While Field Independent shows the process of solving the study perfectly resolved according to the question asked. Students who have a field-independent cognitive style have better understanding of the problem than students who have a fielddependent cognitive style.

In addition, problem solving is one of the characteristics of students who have a cognitive field independent style. The results of this study are in accordance with the statement of Murtafiah (2017) and Wulan \& Anggrain (2019), that Independent Field is capable of organizing information independently and has analytic properties so as to solve mathematical problems. Students who have a field independent cognitive style tend to be creative in solving problems, students are actively participating in the learning process.

Based on the above discussion, The problem of problems expressed by Polya can be used in the main indicators in the resolution of mathematical problems. In addition, in order to achieve The optimal resolution of student mathematics problem, should pay attention to students ' cognitive style primarily based on the Independent field and dependent field

\section{CONCLUSION}

Based on the results of research, data analysis, hypothesis testing, and 
discussion of the results of the study indicate that there are differences in field-independent cognitive styles with a dependent on mathematical problem solving abilities. The characteristic of field independent cognitive style and field dependent is one of the characteristics of students' characteristics that must be considered by teachers in mathematics learning. The math teacher at the beginning of the entry should the teacher do grouping students based on cognitive style. In addition, the headmaster in recruiting students to enter Tsanawiyah Madrasah, not only the value of the results of the National Primary School exam but also needs to be grouped students based on independent and field dependent cognitive field styles.

Students ' advice is expected to find suitable cognitive styles to optimize their mathematical problemsolving skills. For teachers, it is best to conditioned student learning based on cognitive style in mathematics learning. use of learning strategies. For the principal in recruiting students to enter the Tsnawiyah Madrasah, not only judging by the value of the exam results of the national Primary School but also conducting a cognitive-style test of students for researchers, may develop a varied style test and problem-solving.

\section{REFERENCES}

Alifah, N., \& Aripin, U. (2018). Proses Berpikir Siswa SMP dalam Memecahkan Masalah Matematik Ditinjau Dari Gaya Kognitif Field Dependent dan Field Independent. Jurnal Pembelajaran Matematika Inovatif, 1(4), 505-511.

Alvi, M. (2016). A Manual for Selecting Sampling Techniques in Research. Munich Personal RePEc Archive, 1(1), 129-154.
Elita, G. S., Habibi, M., Putra, A., \& Ulandari, N. (2019). Pengaruh Pembelajaran Problem Based Learning dengan Pendekatan Metakognisi terhadap Kemampuan Pemecahan Masalah Matematis. Mosharafa: Jurnal Pendidikan Matematika, 8(3), 447-458.

Huisman, J., \& Tight, M. (2015). Theory and Method in Higher Education Research. Emerald Group Publishing Limited.

Ilmiyana, M. (2018). Ilmiyana, M. (2018). Analisis Kemampuan Pemecahan Masalah Matematika Siswa SMA Ditinjau Dari Tipe Kepribadian. UIN Raden Intan Lampung.

Kafiar, E. (2015). Proses Berpikir Siswa

SMA Dalam Memecahkan

Masalah Matematika Pada Materi SPLTV Ditinjau Dari Gaya Kognitif Field Independent Dan Field Dependent. Jurnal Ilmiah Matematika Dan Pembelajarannya, 1(2).

Lochmiller, C. R., \& Lester, J. N. (2017). An Introduction to Educational Research: Connecting Methods to Practice. SAGE Publications, Inc.

Maimunah, M., Purwanto, P., Sa'dijah, C., \& Sisworo, S. (2016). Penerapan Model Pembelajaran Matematika Melalui Pemecahan Masalah untuk Meningkatkan Penalaran Matematis Siswa Kelas XA SMA Al-Muslimun. Urnal Review Pembelajaran Matematika, 1(1), 17-30.

Mauleto, K. (2019). Analisis

Kemampuan Pemecahan Masalah Ditinjau Dari Indikator NCTM Dan Aspek Berpikir Kritis Matematis Siswa Di Kelas 7b SMP Kanisius Kalasan. JIPMat, 4(2). 
Mourlas, C., Tsianos, N., \& Germanakos, P. (2015). Cognitive and Emotional Processing in WebBased Education: Integrating Human Factors and Personalization. Information Science Refrence.

Murtafiah. (2017). Deskrkipsi kemampuan pemecahan masalah matematika ditinjau dari gaya kognitif mahasiswa pendidikan matematika universitas sulawesi barat. Jurnal Pendidikan MIPA, $7(1), 48-52$.

Nasution. (2013). Berbagai Pendekatan dalam Proses Belajar dan Mengajar. PT. Bumi Aksara.

Nurmutia, H. E. (2019). Pengaruh Gaya Kognitif Terhadap Kemampuan Pemecahan Masalah Matematis Siswa. Edumatika: Jurnal Riset Pendidikan Matematika, 2(2), 98103.

Padliani, P., Bennu, S., \& Rizal, M. (2019). Profil Pemecahan Masalah Persamaan Linear Satu Variabel Siswa Climber Pada Kelas VII SMP Negeri 3 Palu. Mitra Sains, 7(3), 311-320.

Prabawa, E. A., \& Zaenuri, Z. (2017). Analisis Kemampuan Pemecahan Masalah Ditinjau Dari Gaya Kognitif Siswa Pada Model Project Based Learning Bernuansa Etnomatematika. Unnes Journal of Mathematics Education Research, 6(1), 120-129.

Purwaningsih, D., \& Ardani, A. (2020). Kemampuan Pemecahan Masalah Matematis Materi Eksponen dan Logaritma Ditinjau Dari Gaya Belajar dan Perbedaan Gender. AKSIOMA: Jurnal Program Studi Pendidikan Matematika, 9(1), 118-125.
Sajiman, S. ., \& Hasbullah, H. (2016). Developing an Instrument of Measure Cognitif Style Field Dependent and Field Independent In Junior High School Students. Transylvanian Review:, XXIV(5).

Spector, M. J. (2012). Foundations of Educational Technology: Integrative Approaches and Interdisciplinary Perspectives. Routledge.

Stavredes, T. (2011). , Effective Online Teaching: Foundations and Strategies for Student Success. Josse-Bass.

Sunandar, M. A., Zaenuri, Z., \& Dwidayati, N. K. (2018). Mathematical Mathematical Problem Solving Ability Of Vocational School Students On Problem Based Learning Model Nuanced Ethnomatematics Reviewed From Adversity Quotient. Unnes Journal of Mathematics Education Research, 7(1), 115-124.

Suryanti, N. (2014). Pengaruh Gaya Kognitif Terhadap Hasil Belajar Akuntansi Keuangan Menengah 1. Jurnal Ilmiah Akuntansi Dan Humanika, 4(1), 1393-1406.

Ulya, H. (2015). Hubungan gaya kognitif dengan kemampuan pemecahan masalah matematika siswa. Jurnal Konseling GUSJIGANG, 1(2).

Umaru, Y., \& Tukur, H. A. (2013). The Influence Of Dependent And Independent Cognitive Styles On Achievement In Mathematics Among Senior Secondary School Students In Bida Educational Zone Of Niger State, Nigeria. Journal of Research In Education And Society, 4(2), 60-67. 
DOI: https://doi.org/10.24127/ajpm.v9i2.2778

Vendiagrys, L., Junaedi, I., \& Masrukan. (2015). Analisis kemampuan pemecahan masalah matematika soal setipe timss berdasarkan gaya kognitif siswa pada pembelajaran model problem based learning. Unnes Journal of Mathematics Education Research, 4(1), 34-41.

Wulan, E. ., \& Anggrain, R. . (2019). Gaya Kognitif Field-Dependent dan Field-Independent Sebagai Jendela Profil Pemecahan Masalah Polya Dari Siswa SMP. Factor M: Focus ACTion Of Research Mathematic, 1(2), 123-142.

Yousefi, M. (2011). Cognitive Style and EFL Learners' Listening Comprehension Abilty. Indonesian Journal of Applied Linguistics, l(1), 71 . 